\title{
Interactive comment on "TephraKam:
}

Geochemical database of glass compositions in tephra and welded tuffs from the Kamchatka volcanic arc (NW Pacific)" by Maxim V. Portnyagin et al.

\author{
Bärbel Sarbas (Referee) \\ b.sarbas@mpic.de
}

Received and published: 2 December 2019

The term database refers to sets of related data. In the case of TephraKam, there are four individual tables (volcanoes, samples, major elements and trace elements) which are not related. Thus, the comprehensive and unique data collection should not be called database but dataset. 2019. 